\title{
Social Responsibility for Business Companies in the Gulf Cooperation Council Countries: An Applied Study on the Kingdom of Saudi Arabia and Bahrain
}

\author{
Dr. Samah Muhammad Salem \\ Associate Professor - College of Business Administration \\ King Faisal University - Kingdom of Saudi Arabia
}

\section{Introduction}

\section{The concept of social responsibility}

The past years have witnessed a rise in the adoption of social responsibility in profit and nonprofit, as these sectors have realized the importance of adopting this social responsibility concept, which has become equivalent in its value and importance for investment decisions, especially after the countries signed the United Nations Global Compact UNGC, which strengthened the role of social responsibility to become part of the solutions in support of achieving Competitively sustainable.

Different definitions of responsibility take multiple forms of ethical and voluntary obligations for companies that are not only able to achieve profits for the benefit of the shareholders of the company, but also extend to take into account the interest of employees and consumers of their products, and are concerned with social and environmental issues for society as a whole.

Social responsibility concept relates to two dimensions of the activity of any company: the internal governance of the company and the extent of its commitment to the laws in force that guarantee the social rights of its employees and consumers of its products or services, on the one hand, and external governance, i.e. the company deals with local communities outside the context of its business.

None of the definitions provide for a legally binding concept. Rather, the definitions are limited to the obligations that companies define for themselves and adhere to their experience and their vision of their role.

The World Bank define responsibility as "the commitment of economic activity owners to contribute to sustainable development by working with their employees, families, community and society as a whole to improve the standard of living for people in a manner that serves both trade and development" (World Bank, 2005)

The European Commission defines responsibility in 2001 as "a concept through which joint-stock companies voluntarily decide for a better society and a cleaner environment"

The World Business Council for Sustainable Development define social responsibility as "the continuous commitment of business companies to act ethically and contribute to economic development and work to improve the quality of living conditions for the workforce and their families, the community and society as a whole". (WBCSD 1999).

\section{The emergence of concepts of corporate social responsibility and its historical development}

The concept of social responsibility appeared from a long time ago, where many evidences of the private sector's interest in social issues towards the society can be traced. Over decades, researchers have suggested that the concept originated in the thirties of the last century through arguments J Merrick Dodd Merrick. E Dodd on the role of managers. Where he claimed that, in addition to the economic responsibility of company directors towards owners of the businesses, they have a responsibility towards society, because companies operate within a law that authorizes and encourages them to work primarily in the service of society and not to amass profit for company owners only (2011, Gupta and, Taneja.) However, explicit literature on social responsibility is largely the product of the 1950s, according to Carroll, 1999 - and he is one of the first to write about responsibility as employers' obligations to adopt policies, make decisions and actions that are desirable in terms of the goals and values of society according to Carroll (1999). P. 270, Caroll (as stated in, Taneja 2011, Gupta and based on the same "ethical" principle as confirmed by Drucker (1954).

Responsibility is one of the eight main areas that should be focused on in determining the goals of business activities, and he stressed that "it must be considered whether the work is likely to enhance the public interest, to advance the basic beliefs of societies and contribute to their stability, (strength and harmony \& (Padgett, 2011)

Previous opinions faced opposition from a number of economists, including prominent economist Milton Friedman, when he went as far as denouncing the idea that companies have responsibilities towards society, where he said that 
“only people have social responsibility, but the company is A legal person can assume legal responsibilities, but for the business community to bear responsibilities in this mysterious manner, this is not possible. Friedman, (2007) According to the title of his article, "The only social responsibility of companies is to maximize profit, "and as he explains that doing business In the interest of society and the environment in contravention of the primary goal of the company owner, which is maximizing profits, (for example, if the company spends on reducing pollution in excess of the limit prescribed by law), it is considered a failure of the company's right by those in charge of management.

That each person can undertake on his individual responsibility and from his own money, but companies do not have the responsibility to care for society and its interests, as companies are only responsible for paying the salaries of their employees in exchange for their work, providing goods and services to consumers in exchange for what they pay from the price, and paying the taxes due by law, And that any spending outside these areas reduces corporate profitability.

Despite the logical argument of Friedman on the surface, the new administrative studies and trends contradict his direction, as she sees responsibility as an administrative aspect related to improving the company's reputation and governance, which increases society's appetite for its products and maximizes its profits. For example, Walker and Hayes (2005, Hayes) presented a vision that contradicted earlier views, and argued that companies did not exist to shoulder the burden of societal development, and therefore companies should not be judged by looking at their social role, but rather by looking at the way in which they exercise their main work (Gupta and Taneja, 2011) This brings us back to the beginning of protests calling on companies to take social responsibility towards workers and the surrounding community during the period of the Industrial Revolution where there were no restrictions or penalties for violations of workers' rights, and hence children and women were exploited, and factories were located near residential areas without any restrictions.

Carroll (B Carroll, 2008) chronicles some of the practices adopted by businessmen and companies in the stage of the industrial revolution that formed the precursors to form responsibility later, but it indicates that these practices stemmed at the time mainly from companies' interest in making workers more productive and were not For the purpose of providing them with social welfare.

This coincided with severe waves of criticism directed by the reformers in Western countries, specifically, for the emerging factories system at the time as a space for labor unrest, poverty, slums and exploitation of child and women labor in Britain. Social waves emerged from these criticisms that called for the implementation of projects to improve the companies 'performance and improve workers' conditions, such as demanding medical services for them, building toilets, providing lunch rooms and others.

In addition to projects requiring attention to workers' affairs and improving their conditions, some charitable work has been initiated, such as sponsoring businessmen for art, building churches, making donations to educational institutions, and more.

An example that strikes as the closest form of the concept of responsibility is the Chest Community Movement, a fundraising organization that originated between 1918-1929 in Canada and America that was collecting money from companies and workers and redistributing them as social projects. Heald (1970), Support for YMCA (Support for YMCA) is another example of responsibility in that period, as these institutions were donated by businessmen. If these examples refer to some liability practices adopted by companies, Carroll (Carroll, 2008) confirms that these practices did not constitute a general situation during that period, and it is difficult to determine whether these practices are a social responsibility of business organizations or that they are merely individual social responsibility.

\section{Social responsibility in the Gulf Cooperation Council}

The states of the Gulf Cooperation Council realized the importance of social responsibility and directed its initial and continuous efforts in spreading a culture of social responsibility. It directed efforts at the level of individuals and institutions to conform to the needs of the citizen and propose initiatives and solutions in consultation with the competent authorities while serving the march of the development wheel in the GCC countries so that this responsibility becomes a national duty And voluntary initiatives.

From this standpoint, the study looks to identify the reality of social responsibility in some countries of the Cooperation Council (study sample) and to identify the priorities of their needs in terms of projects that achieve social responsibility so that the study serves as a guide for decision makers. It also highlights institutions and companies with social responsibility in all sectors - governmental, private, charitable, and private - and what they have of initiatives that translate social responsibility and identify the beneficiaries of the programs of socially responsible entities and their quality. And a translation of the GCC states' vision that emphasizes the pioneering role in integration and joint action in the field of social responsibility and its values. 


\section{First: The objectives of the study:}

1) Knowing the needs of the states of the Cooperation Council for projects that the social responsibility agencies are interested in.

2) Setting priorities for the needs of the study community

3) List the companies with social responsibility in the GCC countries

4) Learn about the programs and initiatives implemented by socially responsible entities.

5) Determining the beneficiaries and their quality from the programs of socially responsible entities.

\section{Second: The study curriculum:}

To achieve its goals, this study relied on the descriptive research design, which observe and follow a phenomenon or event, relying on qualitative or quantitative information in a specific period of time or during different periods. In order to identify various aspects of the phenomenon and its relationships, to reach results that help in Understanding the current reality to be developed in the future and to determine, analyze and explain the current situation of the reality of social responsibility in the countries of the Cooperation Council, including the survey to study the needs of this region and determine its priorities, and to reveal the programs and initiatives achieved by it, and determine the beneficiaries of that.

\section{Third: Study tools:}

This study rely on the questionnaire as a tool for collecting information as it was distributed and sent to the directors and officials of the targeted companies in the sample size. The following is an explanation of that.

\section{Questionnaire resolution:}

The questionnaire is one of the most common descriptive survey tools and used to obtain data, information and facts related to a specific reality from its direct sources in a relatively short time.

\section{Therefore, three questionnaires were used:}

a. A questionnaire addressed to the managers of companies with social responsibility with the aim of achieving the five goals of the study

b. A questionnaire addressed to managers of companies without social responsibility, with the aim of achieving the first two goals

c. A questionnaire addressed to the managers of charitable societies - private and elite experts in the field of study with a view to achieving the first two goals

The questionnaires went through several steps represented in the following:

\section{-Building the questionnaire}

The study rely on structuring the questionnaire on the research literature related to the subject of the study, and making use of similar research tools, while taking advantage of the directives and personal interviews with the specialists. The study tool has gone through several stages that can be summarized as follows:

-An extrapolation of the research literature with social responsibility in general and in the countries of the Cooperation Council in particular

-Extrapolating the reports of companies with social responsibility in the countries of the Cooperation Council (Saudi Arabia and Bahrain) and after benefiting from the primary and secondary sources related to the subject of the study, the questionnaires were formulated in their initial pictures and presented to a group of researchers - in the field - to express opinion and advice about its paragraphs, and their suitability To measure the goals for which it was set.

-Building questionnaires in their final form of application, and accordingly each questionnaire consisted of the following:

i. Part one: It deals with general data about the questionnaire and its aim.

ii. The second part: It consists of several paragraphs or questions, some of which included study variables and some were prepared - to achieve the goals of the study - in closed form according to the three-dimensional "Likert" scale, while most of the questions were prepared in the open form.

\section{- Validity of the questionnaire:}

Truthfulness refers to the validity of the study tools - used to diagnose a phenomenon or used to collect data necessary to address its topic - to measure what was developed to measure it, or in other words how far it can achieve the goal for which it was designed. The study relied on two types of honesty: 


\section{A) Face Validity:}

Face validity is based on the idea of the suitability of the questionnaire for what you measure, and it is an indicator of the validity of the content. This is often decided by presenting the questionnaire to a group of arbitrators with expertise and experience to conduct its arbitration, after these arbitrators have examined the title of the study, its idea and objectives, then the arbitrators express their opinions and observations about the form and its paragraphs in terms of linking each paragraph with the axis under it, and the clarity of the paragraph and the integrity of its formulation, And suggesting ways to improve it by referring to deletion, staying, or amendment of phrases, etc. According to the arbitrators 'opinions, observations, and recommendations, the questionnaire is modified and its formulation revised so that it is valid for application in its final form. The questionnaires were presented to a number of researchers specialized in the field of social work, statistics, opinion polls and scientific research in order to arbitrate them, and their vision coincided with the inclusion of several paragraphs that greatly serve the objectives desired through this study and for which these questionnaires were designed.

\section{B) Internal Validity:}

It refers to analyzing the content of the questionnaire, and this process usually involves analyzing the elements of the questionnaire by certain statistical methods to find out the possible extent of these elements in distinguishing between the study units in the form.

After verifying the apparent sincerity of the study tool, and in order to identify the internal consistency of the study tool, then the correlation coefficient between the degree of each of the questionnaire expressions has been calculated by the total degree of the axis to which the phrase belongs, as shown in the following two tables:

Table (1): Pearson correlation coefficients with the corporate managers questionnaire for the total score for each main paragraph

\begin{tabular}{|l|l|}
\hline Paragraphs and their phrases & Axis correlation coefficient \\
\hline $\begin{array}{l}\text { Paragraph: the type of support your company provides to other parties } \\
\text { to implement social responsibility programs/ projects }\end{array}$ & 0.178 \\
\hline $\begin{array}{l}\text { Paragraph: The degree to which your company relies on other parties } \\
\text { to implement the social responsibility programs that you support }\end{array}$ & 0.852 \\
\hline $\begin{array}{l}\text { Paragraph: The factors upon which the company's support is provided } \\
\text { for the social responsibility programs that the community needs }\end{array}$ & 0.707 \\
\hline $\begin{array}{l}\text { A paragraph: Your company's business strategy in social responsibility } \\
\text { programs. }\end{array}$ & 0.654 \\
\hline $\begin{array}{l}\text { Paragraph: What is the degree of your company's interest in caring for } \\
\text { the beneficiaries 'interest? }\end{array}$ & 0.746 \\
\hline $\begin{array}{l}\text { Paragraph: What is the degree of your company's interest in social } \\
\text { responsibility programs in the future? }\end{array}$ & 0.739 \\
\hline
\end{tabular}

Table (2) Pearson correlation coefficients with the Phrases of Association Managers at the total level for each main paragraph

\begin{tabular}{|l|l|}
\hline Paragraphs and their phrases & Axis correlation coefficient \\
\hline Young job opportunities & .678 \\
\hline Training the youth for the labor market & .510 \\
\hline Entrepreneurial projects and small projects & .513 \\
\hline Productive families projects & .532 \\
\hline Social and sports clubs & .575 \\
\hline $\begin{array}{l}\text { Caring for the needy (poor widows-families of the deceased } \\
\text { families of prisoners - insolvent - refugees - ...) }\end{array}$ & .673 \\
\hline Patient treatment & .746 \\
\hline Support the next couple to marry & .709 \\
\hline Suitable housing for those in need & .781 \\
\hline Take care of orphans & .736 \\
\hline Soft loans & .699 \\
\hline Caring for people with special needs & .775 \\
\hline Life skills development & .658 \\
\hline talentive sponsoring & .571 \\
\hline Research and studies on community needs & .665 \\
\hline
\end{tabular}




\begin{tabular}{|l|l|}
\hline Paragraphs and their phrases & Axis correlation coefficient \\
\hline Cultural clubs (libraries, quintiles, meetings etc.) & .525 \\
\hline Quality of individual rights and duties towards society & .676 \\
\hline Religious and advocacy quality & .634 \\
\hline Traffic quality & .663 \\
\hline Create recreational and tourist places & .581 \\
\hline $\begin{array}{l}\text { Awareness of environmental conservation (combating } \\
\text { desertification, land reclamation, afforestation, pollution control, } \\
\text { waste recycling, energy, water ... etc) }\end{array}$ & .642 \\
\hline $\begin{array}{l}\text { Public services (facilities development, public transportation, road } \\
\text { repair, infrastructure ...) }\end{array}$ & .706 \\
\hline Intellectual security & .714 \\
\hline $\begin{array}{l}\text { Social investment (adopting the implementation of projects in which } \\
\text { the social return is greater than the profitable commercial return) }\end{array}$ & .743 \\
\hline Health Awareness & .660 \\
\hline Awareness of the public safety of the community & .808 \\
\hline Primary health care & .678 \\
\hline Teaching and memorizing the Holy Quran & .707 \\
\hline Anti begging & .652 \\
\hline Adult literacy & .611 \\
\hline Attention to aesthetics & .578 \\
\hline Legal awareness & .689 \\
\hline
\end{tabular}

It is clear from the previous two tables that the values of the correlation coefficient of each of the phrases with its axis are positive and statistically significant at the level of significance (100, or less), and this indicates that all of the questionnaire statements have a good degree, and confirms the strength of the internal correlation between all the statements of the study tool and therefore this result is clarified Validate phrases and themes of the study tool.

\section{Stability of resolution:}

The consistency of the study tool (the questionnaire) is intended to ensure that the answer will be approximately the same as it is repeated for the people themselves.

Table (3): Alpha Cronbach coefficient to measure the stability of corporate managers questionnaire

\begin{tabular}{|l|l|l|}
\hline Paragraphs and their phrases & $\begin{array}{l}\text { The number of phrases } \\
\text { fixed paragraphs }\end{array}$ & $\begin{array}{l}\text { The number of phrases } \\
\text { fixed paragraphs }\end{array}$ \\
\hline $\begin{array}{l}\text { The type of support your company provides to } \\
\text { other parties to implement social responsibility } \\
\text { programs / projects }\end{array}$ & 5 \\
\hline $\begin{array}{l}\text { The degree to which your company relies on } \\
\text { other parties to implement the social } \\
\text { responsibility programs / projects that you } \\
\text { support }\end{array}$ & .65 & 3 \\
\hline $\begin{array}{l}\text { The factors that depend on providing the } \\
\text { company's support for the social responsibility } \\
\text { programs that the local community needs }\end{array}$ &., 71 & 7 \\
\hline $\begin{array}{l}\text { The strategy of working with your company in } \\
\text { social responsibility programs }\end{array}$ &., 79 & 11 \\
\hline $\begin{array}{l}\text { What is the degree of your company's interest in } \\
\text { caring for the beneficiaries? }\end{array}$ &., 62 & 5 \\
\hline $\begin{array}{l}\text { What is the degree of your company's interest } \\
\text { in social responsibility programs in the future? }\end{array}$ &., 89 & 17 \\
\hline Total &., 853 & $\mathbf{4 8}$ \\
\hline
\end{tabular}

It is clear from the previous table that the value of the Alpha Cronbach coefficient is (.,85) and it is considered a very large value for 48 words that form six main paragraphs, and this means that the coefficient of stability is high and reaches an excellent degree. 
Table (4) Alpha Kronbach laboratories to measure the stability of the association managers' questionnaire

\begin{tabular}{|l|l|}
\hline Paragraphs and their phrases & Fixed paragraphs \\
\hline Young job opportunities & .955 \\
\hline Training the youth for the labor market & .956 \\
\hline Entrepreneurial projects and small projects & .956 \\
\hline Productive families projects & .957 \\
\hline Social and sports clubs & .956 \\
\hline $\begin{array}{l}\text { Caring for the needy (widows- poor- families of the deceased- families of } \\
\text { prisoners - insolvent - refugees ..) }\end{array}$ & .955 \\
\hline Patient treatment & .955 \\
\hline Support the next couple to marry & .955 \\
\hline Suitable housing for those in need & .954 \\
\hline Soft loans & .955 \\
\hline Take care of orphans & .955 \\
\hline Caring for people with special needs & .954 \\
\hline Life skills development & .955 \\
\hline talentive sponsoring & .956 \\
\hline Research and studies on community needs & .955 \\
\hline Cultural clubs (libraries, evenings, meetings, etc.) & .956 \\
\hline Awareness of individual rights and duties towards society & .955 \\
\hline Religious and advocacy awareness & .956 \\
\hline Traffic awareness & .955 \\
\hline Create recreational and tourist places & .956 \\
\hline $\begin{array}{l}\text { Awareness of environmental conservation (combating desertification, land } \\
\text { reclamation, afforestation, water, waste recycling, pollution control, energy, etc.) }\end{array}$ & .955 \\
\hline $\begin{array}{l}\text { Public services (facility development, public transportation, road repair, } \\
\text { infrastructure ...) }\end{array}$ & .955 \\
\hline Intellectual security & .955 \\
\hline Social investment & .955 \\
\hline Health Awareness & .955 \\
\hline Awareness of the public safety of the community & .954 \\
\hline Primary health care & .955 \\
\hline Teaching and memorizing the Holy Quran & .955 \\
\hline Anti begging & .955 \\
\hline Adult literacy & .956 \\
\hline Community interest & .956 \\
\hline Legal awareness & .955 \\
\hline
\end{tabular}

It is clear from the previous table that the value of the Alpha Cronbach coefficient is (.,95) and it is a very large value for 32 key phrases, and this means that the coefficient of stability is high and reaches an excellent degree.

\section{Study and sample community:}

The study community is represented in a sample of companies and institutions in some countries of the Cooperation Council (Saudi Arabia - Bahrain), whether these companies are socially responsible - to assess the reality of social responsibility programs and projects in them - or whether those companies are socially responsible to reveal their orientation towards Implementing social responsibility programs and projects in the future

Where 2250 companies were contacted over the phone to find out whether they have a section on social responsibility or not.

Then all of these companies were contacted through the phone numbers in the data of these companies, but the researcher faced several difficulties during communication with these companies, as many of the phone numbers were incorrect, and some of the numbers were not for the companies registered in the lists, as well That many of them did not respond to the call, despite their attempts to contact them more than three times.

After contacting all the companies, "the original study community", the number of companies that were contacted reached (452) companies, and the following is a description of the study and sample community. 


\section{Study data collection and application steps:}

\section{In its theoretical aspect, the study sought to:}

A. Analysis of the concept of corporate social responsibility

B. Tracking the stages of formation and development of social responsibility in the Kingdom of Saudi Arabia and Bahrain, as well as:

1-An extrapolation of studies and research closely related to the subject of the current study to start from where others ended, and to arrive at the best way to build tools to achieve the study's goals and design

2-Reports of companies with social responsibility in the two countries referred to in the study

3-The First Social Responsibility Forum in Yanbu, "Our Responsibility towards People with Special Needs", organized by the Social Responsibility Council in Yanbu, January 26, 2016.

4-Study, behaviors, desires and trends of donors and supporters of the charitable sector of companies and banks that have social responsibility

\section{On the field side, the data collection stage passed through the following steps:}

1- Inventory of most of the companies and institutions with social responsibility.

2-Distributing the questionnaire to the socially responsible entities, in order to identify the programs and initiatives implemented by these bodies, while specifying the number and type of beneficiaries of those programs

3-Inventorying the private associations and institutions that benefit from companies with social responsibility

4-Conducting contacts and meetings with a number of managers of associations and private institutions, a number of beneficiaries of the services and programs of these associations, with a view to setting priorities for the needs of their local community from projects of socially responsible entities.

\section{Field application difficulties:}

The process of collecting field study data encountered some difficulties, the most important of which can be identified as follows:

1-Many corporate data on address, phone numbers and e-mail are not correct

2-Some company officials refused to cooperate in answering the study questionnaire

3-Poor awareness of some corporate officials about the culture of corporate social responsibility

4-Failure to complete a number of the sample to answer the questionnaire questions, so it was excluded from the sample

\section{Statistical methods used in the study:}

The responses of the study sample were analyzed by officials using the Statistical Package for Social Sciences (SPSS) program, and the following statistical methods were used:

\section{1-Frequencies and percentages}

2-Pearson correlation coefficient for the validity of the questionnaire

3-Alpha Kronbach coefficient to calculate the stability of the questionnaire

4-Quaternities is a method used to divide the iterative distribution into four quarters or equal sections to determine the highest and lowest frequencies after arranging descending order

5-The relative weight (weighted average) equals the numerical estimate of the number of respondents, and the relative weight helps in determining approval of the questionnaire statements and arranging them according to their relative weight. The numerical estimate is calculated by giving a score for each of the responses according to their triangular, quadratic or five-step gradient according to Likert Method

\section{Secondly:}

- Present and discuss the results of the field study

- The needs of the study community (Saudi Arabia - Bahrain)

- The needs of the study community were determined according to their priorities from multiple perspectives, represented in the following entities:

- Corporate social responsibility

- Companies that have an orientation towards implementing social responsibility

- Charities / NGOs implementing social responsibility programs

\section{Specialists and experts:}


Based on the views of the aforementioned entities, the most important needs of the study community were reached, in order of priority, as follows:

- Public services and environmental facilities.

\section{Voluntary and charitable programs:}

Awareness programs (in the religious, advocacy and cultural fields)

- Attention to the categories of society that need care (orphans, widows, people with special needs, the poor, ....) -Attention to clubs and social centers and their programs

\section{Social investment projects:}

- Educational programs and caring for the gifted

- Training youth for the labor market

- Public health and safety programs

It was clear from the application of questionnaires to companies according to their relationship to social responsibility that there are three types:

Companies that implement social responsibility, companies that have a future orientation towards implementing social responsibility, and companies that have no orientation towards implementing social responsibility. The following table and figure show the number and percentage of these companies:

Table (7): Study sample from companies

\begin{tabular}{|l|l|l|l|}
\hline $\mathbf{N}$ & Companies & $\%$ & the number \\
\hline 1 & Social responsibility applies & 21,46 & 44 \\
\hline 2 & $\begin{array}{l}\text { She has a tendency to apply social } \\
\text { responsibility }\end{array}$ & 5,37 & 11 \\
\hline 3 & $\begin{array}{l}\text { She has no orientation to implement } \\
\text { social responsibility }\end{array}$ & 73,17 & 150 \\
\hline & Total Summation & $\mathbf{1 0 0}$ & $\mathbf{2 0 5}$ \\
\hline
\end{tabular}

Through the previous table, it becomes clear that there is an urgent need to activate social responsibility, due to the existence of a large discrepancy indicating that the majority do not have a future orientation towards social responsibility through:

1-Developing corporate leaders 'awareness of the importance of adopting social responsibility

2-Facilitating social investment and granting concessions to those who offer it

3-Integration of economic considerations with social considerations in the business decisions of decision makers

4-Commitment of governments to work on adopting real practices of social responsibility to set an example for the business sector

5-The necessity to make social responsibility an integral part of the institution's strategy, in a clear, specific, organized and sustainable manner. 
Table (8) Corporate strategy in social responsibility programs

\begin{tabular}{|l|l|l|l|l|l|l|l|l|}
\hline $\mathbf{N}$ & Factors on which support depends & \multicolumn{2}{l|}{$\begin{array}{l}\text { Relative } \\
\text { weight }\end{array}$} & \multicolumn{2}{l|}{ SEY } & \multicolumn{2}{l|}{$\begin{array}{l}\text { to some } \\
\text { extent }\end{array}$} & \multicolumn{2}{l|}{ ON } \\
\hline 1 & $\begin{array}{l}\text { The company views social responsibility } \\
\text { programs as secondary }\end{array}$ & 1,23 & 79,5 & 35 & 18,2 & 8 & 2,3 & 1 \\
\hline 2 & $\begin{array}{l}\text { The company has a clear strategy for } \\
\text { exercising social responsibility }\end{array}$ & 2,55 & 6,8 & 3 & 31,8 & 14 & 61,4 & 27 \\
\hline 3 & $\begin{array}{l}\text { The support of the company is limited to } \\
\text { certain social fields, not exceeding it }\end{array}$ & 2,23 & 27,3 & 12 & 22,7 & 10 & 50,0 & 22 \\
\hline 4 & $\begin{array}{l}\text { The company has information about the actual } \\
\text { needs of the local community }\end{array}$ & 2,27 & 15,9 & 7 & 40,9 & 18 & 43,2 & 19 \\
\hline 5 & $\begin{array}{l}\text { There is awareness among the members of the } \\
\text { Board of Directors of the role of social } \\
\text { responsibility in the competitive excellence of } \\
\text { the company }\end{array}$ & 2,59 & 2,3 & 1 & 36,4 & 16 & 61,4 & 27 \\
\hline 6 & $\begin{array}{l}\text { The company has a tendency to increase its } \\
\text { social responsibility programs }\end{array}$ & 2,39 & 13,6 & 6 & 34,1 & 15 & 52,3 & 23 \\
\hline 7 & $\begin{array}{l}\text { The company has a tendency to increase the } \\
\text { target groups of its social responsibility } \\
\text { programs }\end{array}$ & 2,32 & 13,6 & 6 & 40,9 & 18 & 45,5 & 20 \\
\hline 8 & $\begin{array}{l}\text { The company has a tendency to allocate social } \\
\text { responsibility programs that it offers to the } \\
\text { eastern region only }\end{array}$ & 1,98 & 29,5 & 13 & 43,2 & 19 & 27,3 & 12 \\
\hline 9 & $\begin{array}{l}\text { The company requires its partners to submit } \\
\text { final reports on the disbursements of the } \\
\text { support provided to it }\end{array}$ & 2,23 & 29,5 & 13 & 18,2 & 8 & 52,3 & 23 \\
\hline 10 & $\begin{array}{l}\text { The company's support is limited to the entities } \\
\text { located within the company headquarters }\end{array}$ & 1,98 & 31,8 & 14 & 38,6 & 17 & 29,5 & 13 \\
\hline 11 & $\begin{array}{l}\text { There are written systems and regulations } \\
\text { governing the company's social responsibility } \\
\text { work }\end{array}$ & 2,18 & 29,5 & 13 & 22,7 & 10 & 47,7 & 21 \\
\hline
\end{tabular}

It is clear from the previous table and figure that most companies have a "somewhat" clear business strategy in social responsibility programs, as the overall average of the total of these paragraphs was. (2.18).

As for what distinguishes the most important strategy of these companies in social responsibility programs, they were as follows:

- There is awareness among members of the Eastern Region companies' work on social responsibility programs in the company's competitive excellence (2.59) .

- The company has a clear strategy for exercising social responsibility (2.55).

- The company has a tendency to increase its social responsibility programs (2.39).

- The company views social responsibility programs as basic, not secondary, $(2,77)$ - after converting this paragraph from negative to positive, and most companies answered these four paragraphs with "yes."

As for the remaining seven paragraphs, they came within the average relative weight range, where almost half of the companies reported that they implement what related to these paragraphs related to the work strategy in social responsibility programs that they provide to their societies only. The company's support is limited to the entities located within the company's headquarters city

It is also noted from this result that about half of the companies have - to some extent a "future direction" to increase the targeted groups from the social responsibility programs that they offer, the following schedule and form - which express the reality of these companies' interest in the interest of those groups - confirm this:

The following is a table showing the views of workers in social responsibility programs with the targeted companies and the degree of future interest in these programs: 
Table (9): The degree of future interest in the following programs in companies with social responsibility

\begin{tabular}{|c|c|c|c|c|c|c|c|c|c|c|}
\hline \multicolumn{2}{|c|}{ very large } & \multicolumn{2}{|l|}{ large } & \multicolumn{2}{|c|}{$\begin{array}{l}\text { somewhat } \\
\text { large }\end{array}$} & \multicolumn{2}{|l|}{ weak } & \multicolumn{2}{|c|}{ very weak, } & \multirow{2}{*}{$\begin{array}{l}\begin{array}{l}\text { relative } \\
\text { weight }\end{array} \\
4,36\end{array}$} \\
\hline $\begin{array}{l}\text { number } \\
26\end{array}$ & $\begin{array}{l}\% \\
59,1\end{array}$ & $\begin{array}{l}\text { number } \\
10\end{array}$ & $\begin{array}{l}\% \\
22,7\end{array}$ & $\begin{array}{l}\text { number } \\
6\end{array}$ & $\begin{array}{l}\% \\
13,6\end{array}$ & $\begin{array}{l}\text { number } \\
2\end{array}$ & $\begin{array}{l}\% \\
4,5\end{array}$ & $\begin{array}{l}\text { number } \\
\text { 0 }\end{array}$ & $\begin{array}{l}\text { \% } \\
0\end{array}$ & \\
\hline 23 & 52,3 & 8 & 18,2 & 8 & 18,2 & 3 & 6,8 & 2 & 4,5 & 4,07 \\
\hline 22 & 50,0 & 9 & 20,5 & 7 & 15,9 & 2 & 4,5 & 4 & 9,1 & 3,98 \\
\hline 13 & 29.5 & 15 & 34,1 & 12 & 27,3 & 2 & 4,5 & 2 & 4,5 & 3,80 \\
\hline 21 & 47,7 & 6 & 13,6 & 7 & 15,9 & 4 & 9,1 & 6 & 13,6 & 3,73 \\
\hline 12 & 27,3 & 11 & 25,0 & 15 & 34,1 & 3 & 6,8 & 3 & 6,8 & 3,59 \\
\hline 15 & 34,1 & 6 & 13,6 & 15 & 34,1 & 5 & 11,4 & 3 & 6,8 & 3,57 \\
\hline 16 & 36,4 & 11 & 25,0 & 5 & 11,4 & 6 & 13,6 & 6 & 13,6 & 3,57 \\
\hline 9 & 20,5 & 11 & 25,0 & 12 & 27,3 & 9 & 20,5 & 3 & 6,8 & 3,32 \\
\hline 13 & 29,5 & 6 & 13,6 & 6 & 13,6 & 14 & 31,8 & 5 & 11,4 & 3,18 \\
\hline 9 & 20,5 & 6 & 13,6 & 10 & 22,7 & 11 & 25,0 & 8 & 18,2 & 2,93 \\
\hline 4 & 9,1 & 6 & 13,6 & 16 & 36,4 & 12 & 27,3 & 6 & 13,6 & 2,77 \\
\hline 6 & 13,6 & 5 & 11,4 & 13 & 29,5 & 9 & 20,5 & 11 & 25,0 & 2,68 \\
\hline 2 & 4,5 & 9 & 20,5 & 15 & 34,1 & 8 & 18,2 & 10 & 22,7 & 2,66 \\
\hline 1 & 2,3 & 8 & 18,2 & 16 & 36,4 & 12 & 27,3 & 7 & 15,9 & 2,64 \\
\hline 8 & 18,2 & 6 & 13,6 & 4 & 9,1 & 14 & 31,8 & 12 & 27,3 & 2,64 \\
\hline 6 & 13,6 & 4 & 9,1 & 9 & 20,5 & 14 & 31,8 & 11 & 25,0 & 2,55 \\
\hline
\end{tabular}

As for the needs whose degree of importance / need ranged from (8) to less than (9), they were:

- Adequate housing for the needy

- Intellectual security

- Caring for the Gifted

\section{Patient treatment-}

- Legal awareness

- Create recreational places

- Caring for the needy (widows, poor, families of the deceased, families of prisoners, refugees ...)

- Research and studies on community needs

- Awareness of individual rights and duties towards society

- Traffic awareness

- Health awareness

- Primary health care

- Awareness of environmental conservation (combating desertification, land reclamation, afforestation, pollution control, waste recycling, energy, water, etc.)

- Social and sports clubs

- Awareness of the public safety of the community

- Entrepreneurial projects and small projects

- Combating begging

- Development of life skills

- Caring for people with special needs

- Soft loans

- Cultural clubs (libraries, evenings, meetings, etc.)

- Supporting those who are about to get married

- Teaching and memorizing the Holy Quran

- Care for orphans

- Religious and Propaganda Awareness

As for the lowest needs, although the degree of their importance / need for them ranged from (7) to less than

\section{(8), they were:}

- Productive families projects

- Adult literacy

- Attention to communities

In addition to these needs, the specialists in social responsibility programs mentioned other needs that they see as priority, some of which fall under the foregoing, and some of which do not fall under what was mentioned, namely 
Voluntary programs for youth-

- Family management towards building and excellence-

- Increasing places of entertainment, especially children-

- Awareness of children's rights-

- Desalination for all neighborhoods-

\section{Awareness of individual consumption and society or saving and rationalization:}

- Training programs on general taste-

- Increasing agricultural areas-

- Special centers for autistic children-

- Training leaders in the charitable sector-

- Advanced universities and institutes, especially for girls-

It is noted that the questionnaire to determine the priorities of the needs of the study community from the projects that are concerned with social responsibility bodies from the viewpoint of specialists in social responsibility programs have several positive features that can be taken into account in identifying the needs and setting their priorities, including:

- The large number of respondents-

- The diversity of respondents from different sectors of society-

- Respondents' interest in the topic and their keenness to benefit and develop-

- Diversity of respondents-

\section{Detailing community needs, diversity and inclusion-}

In addition to these needs, representatives of charitable societies mentioned other needs that they see as priority, some of which fall under the foregoing, and some of them do not fall under what was mentioned, namely:

- Awareness of drug and smoking harm

- Awareness of traffic accidents-

- Sustainability of community services-

- Adopting individual initiatives

- Measuring the corporate performance index on social responsibility-

- Conducting intensive courses for companies and their employees on social responsibility

- Safety of beaches and seas-

- Banning poaching-

- Investment of retirees-

- Media training-

- Planning for social responsibility programs according to the needs of the geographical region

- Taking care of preparing students for schools and universities-

- Programs to address the weakness of the primary stage-

- Building the capacity of charitable societies, each according to his specialty-

- Young entrepreneurship training-

\section{Providing public transportation for the population:}

From the foregoing, we conclude that it is necessary to implement social responsibility programs and initiatives at the level of all scales and in all areas of development according to deliberate plans that define development priorities, for the areas most in need, and for the poorest segments of the population.

\section{Recommendations:}

In light of the findings of the study on the reality of social responsibility in the two study countries, the most important recommendations that can be drawn out are:

1) The necessity of editing the term social responsibility and distinguishing it from other related terms, such as social responsibility, social response, and charitable or voluntary work.

2) The necessity of educating the study community - individuals and institutions about the culture of social responsibility and the importance of its application in sustaining community development

3) The need to establish sections of social responsibility within the organizational administrative structure of each institution or organization in society

4) The need to make social responsibility an integral part of the institution's strategy in a clear, specific, organized and sustainable way

5) The need to attract competent people to carry out the task of social responsibility while training and continually refining their expertise to support and develop this field 
6) The necessity of implementing social responsibility programs and initiatives at the level of all domains and in all development fields according to studied plans that define development priorities, for the areas most in need, and for the poorest groups of the population.

\section{References}

1. 1-Brent D. (2014). core issues Corporate social responsibility: Definition 'Beal and recent developments. London: Sage Publications Ltd.

2. Elasrag, Hussein (2014. April) Social responsibility of the private sector and its role in sustainable development of the Kingdom of Saudi. 'Arabia .MPRA Paper No. 54977. Online at http://mpra. ub.unimuenchen.de/54977

3. Gravem, Magnus (2010). CSR in Saudi Arabia. Master thesis in religion and society Faculty of Theology-The University of Oslo. http://www.duo.uio.no

4. Working Group on Social Responsibility ISO 26000 (February, 2007).yendyS noitinifed gnikroW

5. eb ot seinapmoc tcepxe sremusnoc sioL, rhoM oD E (2001 ) enirehtaK, sirraH dna ;J harobeD bbeW ;A fo lanruJ ehT .roivaheb gniyub no ytilibisnopser laicos etaroproc fo tcapmi ehT ?elbisnopser yllaicos (35),sriaffA remusnoC)

6. ytilibisnopseR laicoS etaroproC fo esiR ehT .(2013 ).la.te zemaR, idahehS- elbaniatsu rof looT A turieB fo ytisrevinU naciremA, tsaE elddiM eht ni tnempoleveD.

7. World Bank (March, 2007), Opportunities and options for governments promote corporate social responsibility in Europe and central Asia: Evidence from Bulgaria, Croatia and Romania. Working Paper.

8. World Business Council for Sustainable Development (WBCSD) (1999), Meeting changing expectations: Corporate social responsibility. 